REFLEKSI HUKUM

Jurnal Ilmu Hukum
p-ISSN 2541-4984 | e-ISSN 2541-5417

Volume 3 Nomor 1, Oktober 2018, Halaman 1-16

DOI: https://doi.org/10.24246/jrh.2018.v3.i1.p1-16

Open access at: http://ejournal.uksw.edu/refleksihukum Penerbit: Fakultas Hukum Universitas Kristen Satya Wacana

\title{
PERTANGGUNGJAWABAN PIDANA OLEH PENGURUS KORPORASI DIKAITKAN DENGAN ASAS GEEN STRAF ZONDER SCHULD
}

\author{
Fifink Praiseda Alviolita \\ Magister Ilmu Hukum Universitas Diponegoro \\ Korespondensi: fifinkpraiseda@gmail.com
}

\begin{abstract}
Abstrak
Peraturan terkait pertanggungjawaban tindak pidana korporasi telah diatur dalam berbagai peraturan perundang-undangan. Perluasan makna pertanggungjawaban atas tindak pidana yang dilakukan oleh pengurus korporasi apabila orang tersebut tidak memenuhi kewenangan pasca dikeluarkannya Perma Nomor 13 Tahun 2016 tentang Tata Cara Penanganan Korporasi untuk mewakili dalam persidangan yang bertentangan dengan asas geen straft zonder schuld dimana pertanggungjawaban harus ada kesalahan. Penelitian ini adalah penelitian yuridis normatif dengan pendekatan perundang-undangan dan pendekatan konseptual. Sistem pertanggungjawaban korporasi yang dipakai di dalam Perma adalah konsep pertanggungjawaban strict liability maka seharusnya teori yang digunakan adalah teori identifikasi dimana perbuatan tindak pidana korporasi adalah perbuatan pengurus yang menjadi directing mind. Keterwakilan pengurus yang tidak menjadi tersangka dalam mewakili korporasi adalah melewati proses hukum acara pidana dimana keterwakilan ini seharusnya dibatasi sebagai wujud perlindungan hukum.
\end{abstract}

Kata Kunci: Geen Straft Zonder Schuld; Korporasi; Pertanggungjawaban Pengurus.

\begin{abstract}
The regulations related to the accountability of corporate crime have been regulated in various laws and regulations. An expansion of the meaning of accountability for criminal acts is carried out by corporate management, defining that the person does not fulfill the authority (after the issuance of PERMA Number 13 of 2016 concerning Corporate Handling Procedures) to represent the trial as opposed to the geonder straft zul schuld principle where accountability must be wrong. This study uses normative juridical research with a statutes approach and a conceptual approach. The corporate liability system used in PERMA is the concept of strict liability accountability, so that the theory should be the theory of identification where acts of corporate crime are acts of management that becomes directing mind. The representation of the board that is not a suspect in representing the corporation is through criminal procedure where this representation should be limited as a form of legal protection.
\end{abstract}

Keywords: Geen Straft Zonder Schuld; Corporate; Responsibility Of Committee. 


\section{PENDAHULUAN}

Perkembangan ilmu pengetahuan dan teknologi memiliki pengaruh pada perkembangan masyarakat dan perkembangan subjek tindak pidana yang semula hanya dikenal dapat dilakukan oleh manusia alamiah (naturlijk persoon), tetapi juga dapat dilakukan oleh badan hukum (recht persoon) atau korporasi. ${ }^{1}$ Pada saat ini, peran korporasi dalam berbagai kegiatan produksi cukup besar, hal ini mengakibatkan suatu perusahaan atau korporasi ingin memperoleh keuntungan yang sebesar-besarnya (profit oriented). Dalam hal ini korporasi dapat melakukan perbuatan yang membahayakan bagi masyarakat. ${ }^{2}$ Bahaya tersebut dapat berupa bahaya terhadap lingkungan maupun terhadap kesehatan manusia. Mardjono Reksodipuro menyatakan bahwa kerugian yang ditimbulkan akibat kejahatan korporasi begitu besar. ${ }^{3}$ Misalnya dalam hal penayangan iklan yang menyesatkan, barang produksi tidak aman, maupun pencemaran lingkungan hidup yang menimbulkan bahaya bagi masyarakat. Tipologi korban kejahatan korporasi bukan hanya masyarakat namun juga negara. ${ }^{4}$

Mengingat dampak kejahatan korporasi yang dapat menimbulkan bahaya bagi masyarakat maka pemerintah Indonesia melalui lembaga legislatif beserta eksekutifnya membentuk bebe- rapa peraturan terkait korporasi khususnya dalam hal tindak pidana khusus atau kejahatan extraordinary crime. $^{5}$ Beberapa peraturan terkait pertanggungjawaban korporasi tersebar pada beberapa peraturan perundangundangan di Indonesia yaitu: UndangUndang Nomor (UU No.) 31 Tahun 1999 tentang Pemberantasan Tindak Pidana Korupsi sebagaimana telah diubah dengan UU No. 20 Tahun 2001, UU No. 36 Tahun 2009 tentang Kesehatan, UU No. 32 Tahun 2009 tentang Perlindungan dan Pengelolaan Lingkungan Hidup, UU No. 8 Tahun 1999 tentang Perlindungan Konsumen, UU No. 31 Tahun 2014 tentang Perlindungan Saksi dan Korban, dan lain-lain. Meskipun banyak peraturan korporasi yang diatur melalui beberapa perundang-undangan yang berlaku di Indonesia, namun peraturan ini belum efektif dalam menjerat pelaku tindak pidana korporasi hal ini ditandai dengan perkara dan subjek hukum yang diajukan di pengadilan sangat terbatas sebab prosedur dan tata cara pemeriksaan korporasi sebagai pelaku tindak pidana masih belum jelas. Hal ini dapat dilihat hanya ada beberapa korporasi yang menjadi subjek hukum di pengadilan misalnya PT Don Woon Enviromental, PT Adei dan PT Kalista Alam dalam kasus lingkungan hidup, PT National Sago Prima dalam kerusakan lahan, PT Percetakan dan Penerbitan

I Dewa Made Suartha, Hukum Pidana Korporasi (Pertanggungjawaban Pidana dalam Kebijakan Hukum Pidana Indonesia) (Setara Press 2015) 3.

Ibid., 4.

Ibid., 5.

Hanafi Amran dan Mahrus Ali, Sistem Pertanggungjawaban Pidana (Perkembangan dan Penerapan) (Rajawali Pers 2015) 145.

5 Kejahatan Extraordinary crime adalah kejahatan yang sistematis dan meluas serta dapat menimbulkan pelanggaran hak sosial dan hak ekonomi bagi masyarakat. 
Sulawesi dalam kasus pidana pajak. ${ }^{6}$ Kemudian dengan dibentuknya Peraturan Mahkamah Agung Nomor 13 Tahun 2016 tentang Tata Cara Penanganan Korporasi (selanjutnya disebut Perma No. 13/2016) diharapkan mengisi adanya kekosongan hukum terkait penanganan tindak pidana korporasi sebagai subjek hukum. ${ }^{7}$ Dengan adanya Perma No. 13/2016, disisi lain terdapat kelebihan dan disisi lain ada kelemahan. Kelemahan di dalam Perma No. 13/2016, menurut Institute for Criminal Justice Reform (ICJR) dan Masyarakat Profesi Penilai Indonesia (MAPPI) antara lain adalah pengaturannya masih bersifat transisi dan belum utuh. Aturan di dalam Perma No. 13/2016 ada yang masih tumpang tindih dengan aturan yang lain, pengaturan hanya bersifat formalprosedural, belum mengatur terkait korporasi dengan bentuk non badan hukum, tidak adanya batasan dalam hal menentukan suatu perbuatan yang dilakukan oleh seseorang dikategorikan sebagai tindakan korporasi dan bertanggungjawab atas tindak pidana yang dilakukan oleh korporasi apabila orang tersebut tidak memenuhi kewenangan, tidak adanya sanksi tambahan atau sanksi tata tertib. ${ }^{8}$ Dalam Perma No. 13/2016 tersebut sanksi pokoknya adalah sanksi denda, di samping itu juga diatur mengenai sanksi tambahan yakni pencabutan izin usaha, pencabutan status badan hukum, perampasan keuntungan, penutupan sebagian atau seluruhnya perusahaan, perbaikan akibat dari tindak pidana dan lain-lain.

Terkait pengaturan mengenai pengurus korporasi di dalam Perma No. $13 / 2016$, menurut penulis terdapat adanya ketidakjelasan yaitu terdapat di dalam Pasal 15 yang menyatakan:

1. Dalam hal Korporasi diajukan sebagai tersangka atau terdakwa dalam perkara yang sama dengan Pengurus, maka Pengurus yang mewakili Korporasi adalah Pengurus yang menjadi tersangka atau terdakwa.

2. Pengurus lainnya yang tidak menjadi tersangka atau terdakwa dapat mewakili Korporasi dalam perkara sebagaimana dimaksud pada ayat (1).

Pada pasal tersebut menurut penulis tidak ada batasan terkait kapasitas pengurus dalam sistem peradilan pidana atau keterwakilan pengurus dalam beracara di pengadilan terhadap perkara tindak pidana yang subjek hukumnya dilakukan oleh korporasi. Dalam hal ini menimbulkan pertanyaan apakah bertentangan dengan asas geen straft zonder schuld dimana pertanggungjawaban itu harus ada kesalahan. Penelitian ini menggunakan metode penelitian yuridis normatif melalui pendekatan peraturan perundang-undangan (statue approach) dan pendekatan konsep (conceptual approach).Interpretasi yang digunakan adalah interpretasi sistematis dan inter-

6 Anonim, 'Mendorong Penegakan Pertanggungjawaban Korporasi dalam Perkara Pidana: Perma No.13 Tahun 2016 dan Tantangannya' (2017) <http://icjr.or.id/mendorong-penegakan-pertanggung jawaban-korporasi-dalam-perkara-pidana-perma-no-13-tahun-2016-dan-tantangannya/> diakses 15 Mei 2018.

$7 \quad$ Ibid.

$8 \quad$ Ibid. 
pretasi gramatikal. Semua peraturan perundang-undangan yang berkaitan dengan penelitian ini dianalisis dengan jalan menghubungkan satu dengan yang lainnya untuk menjawab permasalahan yang ada.

Berdasarkan pemaparan permasalahan di atas, adapun rumusan masalah dalam penulisan ini adalah sebagai berikut: 1. Apakah kriteria pertanggungjawaban pengurus yang mewakili pelaku tindak pidana korporasi dalam Peraturan Mahkamah Agung Nomor 1 tahun 2014? 2. Bagaimana bentuk pertanggungjawaban pengurus yang mewakili pelaku tindak pidana korporasi dalam sistem peradilan pidana/hukum acara pidana yang berlaku untuk kejahatan korporasi?

\section{PEMBAHASAN}

\section{Kriteria Pertanggungjawaban Peng- urus Yang Mewakili Pelaku Tindak Pidana Korporasi Dalam Perma No. $13 / 2016$}

Asas legalitas menghendaki adanya ketentuan yang pasti terlebih dahulu mengenai perbuatan yang dilarang maupun ketentuan pidana yang dijatuhkan kepada pelaku begitu juga dengan pertanggungjawaban pidana pada korporasi maupun pengurusnya sebagaimana yang dikemukakan oleh Simons, Van Hamel, Van Hattum bahwa adanya asas legalitas bermanfaat untuk menjamin kepastian hukum dari adanya kesewenang-wenangan hakim sedangkan Vos mengungkapkan bahwa asas legalitas memiliki manfaat di samping kekuatan pencegah umum ancaman pidana juga menjamin adanya kepastian hukum. ${ }^{9}$ Dalam bahasa Belanda korporasi dikenal dengan istilah corporatie sedangkan dalam bahasa Inggris dan Jerman disebut corporation $^{10}$ dan berasal dari bahasa latin yaitu corporatio. ${ }^{11}$ Korporasi merupakan badan hukum yang merupakan subjek hukum sebagaimana orang perseorangan atau individu sehingga korporasi apabila melakukan tindak pidana dapat dipertanggungjawabkan. ${ }^{12}$ Korporasi merupakan badan hukum yang memiliki hak dan kewajiban serta dapat melakukan perbuatan hukum. ${ }^{13}$ Perbuatan korporasi yang dapat dikatakan sebagai tindak pidana sudah dirumuskan dalam beberapa peraturan perundang-undangan di Indonesia dan dalam memudahkan penegak hukum untuk penanganan tindak pidana korporasi, Kejaksaan menerbitkan Peraturan Jaksa Agung Republik Indonesia Nomor (Perja No): PER-028/A/JA/10/2014 Tanggal 1 Oktober 2014 tentang Pedoman Penanganan Perkara Pidana

$9 \quad$ Mulyati Prawennei dan Rahmanuddin Tomalili, Hukum Pidana (Mitra Wacana Media 2015$) 73$.

10 Muladi dan Dwidja Priyatno, Pertanggung Jawaban Pidana Korporasi (Edisi Revisi, Kencana Prenada Media Group 2012) 23.

11 Corporatio berasal dari kata kerja Corporare sedangkan corporare berasal dari corpus yang berarti badan sehingga corporation adalah hasil dari pekerjaan membadankan atau dengan kata lain badan yang dijadikan orang, badan yang diperoleh dengan perbuatan manusia sebagai lawan terhadap badan manusia yang terjadi menurut alam.

12 Adriano, Pemikiran dan Teknik Pembuatan Putusan Pemidanaan Terhadap Korporasi (Mandar Maju 2016) 11.

13 Ibid. 
Dengan Subjek Hukum Korporasi. ${ }^{14}$ Perja tersebut mengatur mengenai penjatuhan tuntutan pidana oleh Jaksa pada tindak pidana korporasi yang dapat diajukan kepada korporasi, pengurus korporasi, serta korporasi dan pengurus korporasi. Namun apabila undang-undang tidak mengatur mengenai subjek hukum korporasi maka tuntutan pidana diajukan kepada pengurusnya. Setelah petunjuk teknis dikeluarkan oleh Kejaksaan selanjutnya Mahkamah Agung mengeluarkan Perma No. 13/2016. Pengertian korporasi dalam Perma tersebut terdapat pada Pasal 1 ayat (1) yang menyatakan bahwa korporasi adalah kumpulan orang dan/ atau kekayaan yang tergorganisir, baik merupakan badan hukum maupun bukan badan hukum.

Perma No. 13/2016 ini mengatur terkait tata cara penanganan perkara tindak pidana korporasi yang tersebar di dalam peraturan perundang-undangan yang memuat korporasi sebagai subjek hukum. Tindak pidana korporasi merupakan tindak pidana yang dilakukan oleh orang berdasarkan hubungan kerja, atau hubungan lain, baik sendiri- sendiri maupun secara bersama-sama bertindak untuk dan atas nama korporasi di dalam maupun di luar lingkungan korporasi. Hukuman pidana bagi korporasi dalam aturan ini hanya hukuman denda dan jika korporasi tidak mampu membayar maka aparat berhak untuk menyita aset dan kemudian untuk dilelang sebagai pengganti kerugian negara. ${ }^{15}$

Terkait dengan subjek pertanggungjawaban korporasi diatur dalam Pasal 23 Perma No. 13/2016.16 Dalam hal ini yang dapat dijadikan subjek hukum dalam pertanggungjawaban korporasi adalah: 17

1. Korporasi atau Pengurus;

2. Korporasi dan Pengurus;

3. Pihak lain yang terbukti terlibat dalam tindak pidana korporasi.

Korporasi sebagai subjek hukum dalam sistem hukum pidana Indonesia dapat dibedakan antara yang melakukan tindak pidana (pembuat) dan yang bertanggungjawab hal ini bergantung pada sistem perumusan pertanggungjawaban pidana yang akan digu-

14 Stefanus Kurniawan Dharmadji, 'Pertanggungjawaban Pidana Korporasi Pasca Perma No. 13 Tahun 2016' (2017) <http://weloje.id/news-posts/pertanggungjawaban-pidana-korporasi-pasca-perma-no13-tahun-2016/> diakses 15 Mei 2018.

15 Anonim, 'Mendorong Penegakan Pertanggungjawaban Korporasi dalam Perkara Pidana: Perma No.13 Tahun 2016 dan Tantangannya' (2017) <http://icjr.or.id/mendorong-penegakan-pertanggungja waban-korporasi-dalam-perkara-pidana-perma-no-13-tahun-2016-dan-tantangannya/> diakses 15 Mei 2018.

16 Dalam Bab III Tentang Putusan dan Pelaksanaan Putusan Pengadilan, Bagian Kesatu Tentang Penjatuhan Pidana, Pasal 23 menyatakan:

(1) Hakim dapat menjatuhkan pidana terhadap Korporasi atau Pengurus, atau Korporasi dan Pengurus.

(2) Hakim menjatuhan pidana sebagaimana dimaksud pada ayat (1) didasarkan pada masingmasing undang-undangyang mengatur ancaman pidana terhadap Korporasi dan/atau Pengurus.

(3) Penjatuhan pidana terhadap Korporasi dan/atau Pengurus sebagaimana dimaksud ayat (1) tidak menutup kemungkinan penjatuhan pidana terhadap pelaku lain yang berdasarkan ketentuan undang-undang terbukti terlibat dalam tindak pidana tersebut.

17 Dalmy Nasution, 'Siapakah Yang Bertanggungjawab Jika Terjadi Tindak Pidana Korporasi?' <https:/ / bplawyers.co.id/2017/07/11/siapakah-yang-bertanggung-jawab-jika-terjadi-tindak-pidan a-korporasi/> diakses 15 Mei 2018. 
nakan. ${ }^{18}$ Pasal 1 ayat (8) tindak pidana oleh korporasi adalah tindak pidana yang dapat dimintakan pertanggungjawaban pidana kepada korporasi sesuai dengan UU yang mengatur tentang korporasi. Dalam Perma, hakim menyatakan korporasi melakukan kesalahan yang dapat dipidana, bilamana:

1. Korporasi dapat memperoleh keuntungan atau manfaat dari tindak pidana tersebut atau tindak pidana tersebut dilakukan untuk kepentingan korporasi;

2. Korporasi membiarkan terjadinya tindak pidana;

3. Korporasi tidak melakukan langkah -langkah yang diperlukan untuk melakukan pencegahan, mencegah dampak yang lebih besar dan memastikan kepatuhan terhadap ketentuan hukum yang berlaku guna menghindari terjadinya tindak pidana.

Sedangkan pengertian pengurus korporasi diatur di dalam Pasal 1 ayat (10) Perma No. 13/2016 yaitu "Pengurus adalah organ korporasi yang menjalankan korporasi sesuai anggaran dasar atau UU yang berwenang mewakili korporasi, termasuk mereka yang tidak memiliki kewenangan untuk mengambil keputusan, namun dalam kenyataannya dapat mengendalikan atau turut mempengaruhi kebijakan korporasi atau turut memutuskan kebijakan korporasi yang dapat dikualifikasikan sebagai tindak pidana."

Pasal tersebut menyebutkan bahwa baik pengurus yang memiliki kewenangan maupun pengurus yang tidak memiliki kewenangan dapat menjadi subjek hukum tindak pidana korporasi apabila dalam kenyataanya pengurus tersebut dapat mengendalikan, mempengaruhi kebijakan korporasi turut memutuskan kebijakan korporasi dapat dikualifikasikan sebagai tindak pidana. Terkait pengurus yang mewakili pelaku tindak pidana korporasi atau pengurus yang mewakili korporasi yang dijadikan sebagai tersangka dalam perkara yang sama dengan pengurus adalah sebagaimana yang diatur di dalam Pasal 15 Perma No. 13/2016 yang menyatakan:

(1) Dalam hal Korporasi diajukan sebagai tersangka atau terdakwa dalam perkara yang sama dengan Pengurus, maka Pengurus yang mewakili Korporasi adalah Pengurus yang menjadi tersangka atau terdakwa.

(2) Pengurus lainnya yang tidak menjadi tersangka atau terdakwa dapat mewakili Korporasi dalam perkara sebagaimana dimaksud pada ayat (1).

Pengurus yang mewakili yang dimaksud oleh penulis adalah pengurus lainnya yang tidak menjadi tersangka atau terdakwa dapat mewakili korporasi dalam hal korporasi diajukan sebagai tersangka atau terdakwa dalam perkara yang sama dengan pengurus yang mana dalam Pasal 15 ayat (1) apabila korporasi diajukan sebagai tersangka atau terdakwa dalam perkara yang sama dengan pengurus maka pengurus yang mewakili korporasi adalah pengurus yang menjadi tersangka atau terdakwa. Dalam hal ini kriteria pertanggungjawaban pengurus yang mewaki-

18 Jegesson P. Situmorang, Pujiyono, Amiek Soemarmi, 'Pertanggungjawaban Pidana Korporasi dalam Menanggulangi Tindak Pidana Perikanan’ (2016) 5 Diponegoro Law Journal, 1, 7. 
li korporasi adalah memakai strict liability yang mana mengesampingkan adanya unsur kesalahan dimana di dalam hukum pidana terdapat asas geen straf zonder schuld yaitu hukuman tanpa kesalahan artinya tak seorangpun dapat dijatuhi pidana jika tidak ada kesalahan yang ia perbuat. ${ }^{19}$ Perbandingan dengan negara yang menganut common law system, strict liability merupakan tindak pidana yang ditentukan oleh peraturan perundangundangan (statute). ${ }^{20}$ Kesalahan tersebut harus memenuhi unsur diantaranya dilakukannya perbuatan pidana, mampu bertanggungjawab, dilakukan dengan kesengajaan atau kealpaan dan tidak ada alasan pemaaf bagi pelaku. ${ }^{21}$ Adanya kesalahan bukan hanya menentukan dapat dipertanggungjawabkannya pembuat namun juga dapat dipidananya pembuat. ${ }^{22}$

\section{Pertanggungjawaban Pengurus yang mewakili Pelaku Tindak Pidana Korporasi Dikaitkan dengan Asas Geen Straft Zonder Schuld}

Pada suatu tindakan pengurus korporasi pertanggungjawaban atasnya harus dipastikan memenuhi kewenangan atau perintah untuk melakukan kejahatan bersama korporasi dengan menghendaki untuk melakukan perbuatan (mens rea). Dalam penjelasan Pasal 20 ayat (1) UU No. 31/1999 jo. UU No. 20/2001 menyebutkan yang dimaksud dengan pengurus adalah organ korporasi yang menjalankan kepengurusan korporasi yang bersangkutan sesuai dengan anggaran dasar, termasuk mereka yang dalam kenyataannya memiliki kewenangan dan ikut memutuskan kebijakan korporasi yang dapat dikualifikasikan sebagai tindak pidana korupsi. Dalam hal ini pengurus korporasi adalah pengurus yang memang memiliki kewenangan dalam menjalankan korporasi. Sehingga dalam hal ini wewenang menjadi unsur penting dalam suatu pertanggungjawaban.

Dalam hal pertanggungjawaban korporasi dikenal dengan asas strict liability yang merupakan doktrin pertanggungjawaban pidana korporasi yang diadopsi dari doktrin hukum perdata, yakni doktrin yang diterapkan dalam perbuatan melawan hukum. Dalam hal korporasi melanggar atau tidak memenuhi kewajiban/ kondisi/ situasi tertentu oleh korporasi ini dikenal dengan istilah "companies offence", "situational offence", atau "strict liability offences". Misal UU menetapkan sebagai suatu delik bagi: 23

1. Korporasi yang menjalankan usahanya tanpa izin.

2. Korporasi pemegang izin yang melanggar syarat-syarat (kondisi/ situasi) yang ditentukan dalam izin itu.

3. Korporasi yang mengoperasikan kendaraan yang tidak diasuransikan di jalan umum.

19 Sebagaimana yang diatur di dalam Pasal 44 Jo. Pasal 45 KUHP.

20 Yudi Krismen, 'Pertanggungjawaban Pidana Korporasi dalam Kejahatan Ekonomi' (2014) 4 Jurnal Ilmu Hukum 133, 155.

21 Didik Endro Purwoleksono, Hukum Pidana (Airlangga University Press 2014) 63.

22 Chairul Huda, Dari Tiada Pidana Tanpa Kesalahan Menuju Kepada Tiada Pertanggungjawaban Pidana Tanpa Kesalahan (Prenadamedia Group 2015) 132.

23 Barda Nawawi Arief, Kapita Selekta Hukum Pidana (Cetakan ke-3, Citra Aditya Bakti 2013$) 197$. 
Dalam hukum pidana asas strict liability merupakan doktrin yang mengesampingkan unsur kesalahan atau unsur mens rea dalam pertanggungjawaban pidana. Doktrin ini menyimpangi asas utama dalam hukum pidana yaitu asas mens rea itu sendiri. Dimana ketentuan strict liability merupakan pengecualian dari asas tiada pidana tanpa kesalahan (Geen Straft Zonder Schuld). Sedangkan menurut Vos memandang pengertian kesalahan sebagai berikut: 24

1. Kemampuan bertanggung jawab dari orang yang melakukan perbuatan.

2. Hubungan batin tertentu dari orang yang berbuat, yang perbuatannya itu dapat berupa kealpaan atau kesengajaan.

3. Tidak ada alasan yang menghapus pertanggungjawaban bagi pelaku atas perbuatannya.

Lahirnya pengecualian ini merupakan perluasan dan pendalaman asas regulatif, moral yaitu dalam hal-hal tertentu bertanggung jawab seseorang dipandang patut diperluas sampai ke tindakan bawahannya yang melakukan pekerjaan atau perbuatan untuknya atau dalam batas-batas perintahnya. ${ }^{25}$ L.B. Curson berpendapat bahwa doktrin ini dapat diterapkan pada kondisikondisi sebagai berikut:

1. Menjamin dipatuhinya peratu-ranperaturan yang berkaitan dengan kesejahteraan sosial adalah
esensial;

2. Pembuktian terkait dengan asas mens rea sulit diberlakukan terhadap pelanggaran-pelanggaran yang berhubungan dengan kesejahteraan sosial;

3. Adanya dampak yang sangat berbahaya akibat perbuatan yang dilakukan.

Terkait dengan tindak pidana korporasi doktrin ini dapat diterapkan pada pertanggungjawaban pidana korporasi yang menyangkut perlindungan terhadap kepentingan umum atau kepentingan masyarakat serta kejahatan terhadap lingkungan hidup. Menjadi problematika disini yakni sebagaimana pada Pasal 15 pada Perma 13/ $2016^{26}$ mengatur pertanggungjawaban pidana korporasi yang dilakukan oleh pengurus dengan menggunakan asas strict liability. Dalam ketentuan Pasal tersebut tidak terdapat kejelasan mengenai siapa pengurus yang dapat mewakili korporasi dalam terdapat suatu perkara antara korporasi dengan pengurus pelaku tindak pidana korporasi. Apakah pengurus tersebut masuk termasuk di dalam pasal 1 angka 10 Perma yaitu pengurus yang memiliki kewenangan dan tidak memiliki kewenangan atau pengurus yang memang memiliki kewenangan dalam mengendalikan korporasi dalam hal terjadinya tindak pidana.

\footnotetext{
$24 \quad$ Ibid., 137

25 Muladi dan Dwidja Priyatno, Op.Cit. 115.

26 Pasal 15, Perma No. 13 Tahun 2016 menyatakan:
}

(1) Dalam hal Korporasi diajukan sebagai tersangka atau terdakwa dalam perkara yang sama dengan Pengurus, maka Pengurus yang mewakili Korporasi adalah Pengurus yang menjadi tersangka atau terdakwa.

(2) Pengurus lainnya yang tidak menjadi tersangka atau terdakwa dapat mewakili Korporasi dalam perkara sebagaimana dimaksud pada ayat (1). 
Pada pasal tersebut maka mens rea tidak perlu dibuktikan sebagaimana pendapat Barda Nawawi Arief, yakni terkait strict liability yang menyatakan bahwa seseorang sudah dapat dipertanggungjawabkan untuk tindak pidana tertentu walaupun pada diri orang itu walaupun tidak perlu dibuktikan kesalahan terdakwa (mens rea). Secara singkat, strict liability diartikan sebagai "liability without faul'" atau pertanggungjawaban tanpa kesalahan. ${ }^{27}$ Namun kesalahan merupakan salah satu unsur dari seseorang dianggap mampu bertanggung jawab atas suatu tindak pidana. Hal tersebut nantinya juga akan menentukan sejauh mana pengurus bertanggung jawab terhadap tindak pidana yang dilakukan oleh suatu korporasi. Hubungan antara pengurus satu dan yang lainnya dilakukan dalam konteks rangkaian kerja antar manusia, in casu melalui suatu organisasi tertentu yang disebut korporasi. Karena itu wajar apabila dinyatakan bahwa para pelaku tersebut bertanggungjawab atas akibat yang dianggap secara adequat muncul dari perluasan lingkup perbuatan mereka. Namun akan dialami kesulitan sejauh mana letak batas tanggung jawab tersebut.

Kesalahan disini terkait dengan asas geen straf zonder schuld yaitu tiada pidana tanpa kesalahan yang merupakan pengecualian dari asas strict liability. Mengutip pendapat Sudarto dalam memaknai kesalahan dimana dipidananya seseorang tidaklah cukup apabila orang itu telah melakukan perbuatan yang bertentangan dengan hukum atau bersifat melawan hukum. Jadi meskipun pembuatnya memenuhi rumusan delik dalam UU dan tidak dibenarkan namun hal tersebut belum memenuhi syarat untuk dijatuhi pidana.28 Terkait pengertian pengurus dalam Pasal 1 angka 10 Perma No. 13/2016 terdapat perluasan penarikan pertanggungjawaban "pengurus" termasuk mereka yang tidak memiliki kewenangan untuk mengambil keputusan, namun dalam kenyataannya dapat mengendalikan atau turut mempengaruhi kebijakan korporasi atau turut memutuskan kebijakan dalam korporasi. Perluasan ini perlu menjadi pertanyaan kemudian bagaimana batasannya dalam hal menentukan suatu perbuatan yang dilakukan oleh seseorang dikategorikan sebagai tindakan korporasi dan bertanggungjawab atasnya apabila orang tersebut (pengurus) tidak memiliki kewenangan bahkan ia tidak mempunyai mens rea pada Pasal 15 ayat (2) dalam Perma No. 13/2016 ia dapat mewakili dalam persidangan.

Apabila dikaitkan dengan beberapa teori pertanggungjawaban pidana korporasi seperti "identification theory" maka tetap disyaratkan kedudukan dan kewenangan dari orang yang bersangkutan dikaitkan dengan tindak pidana yang dilakukan. ${ }^{29}$ Doktrin ini berasal

27 Barda Nawawi Arief, Pelengkap Bahan Kuliah Hukum Pidana I (Fakultas Hukum Universitas Diponegoro 1984) 68.

28 Muladi dan Dwidja Priyatno, Op. Cit., 71.

29 Anonim, 'Mendorong Penegakan Pertanggungjawaban Korporasi dalam Perkara Pidana: Perma No.13 Tahun 2016 dan Tantangannya' (2017) <http://icjr.or.id/mendorong-penegakan-pertanggungjawa ban-korporasi-dalam-perkara-pidana-perma-no-13-tahun-2016-dan-tantangannya/> diakses 15 Mei 2018. 
dari negeri Anglo Saxon. Muladi berpendapat bahwa doktrin identifikasi sebuah perusahaan dapat melakukan sejumlah delik secara langsung melalui orang-orang yang sangat berhubungan erat dengan perusahaan. Dening L. J. berpendapat bahwa sikap kalbu dari manajer merupakan sikap kalbu dari perusahaan itu sendiri. Doktrin Identifikasi juga sering disebut sebagai alter ego theory. Orang yang memiliki kedudukan yang tinggi seperti high level manager dianggap sebagai directing mind and will dari korporasi sehingga mens rea adalah terletak dari individu yang menjadi directing mind dari korporasi tersebut. Dari putusan the supreme court of Canada, terdapat tiga kondisi yang dapat diberlakukannya identification theory ini, antara lain sebagai berikut: 30

1. Directing mind dari suatu korporasi tidak terbatas pada satu orang saja, melainkan juga sejumlah pejabat dan direktur;

2. Perbedaan wilayah bukanlah menjadi alasan seseorang tidak dapat disebut sebagai directing mind;

3. Suatu korporasi tidak dapat mengelak untuk bertanggung jawab dengan mengemukakan bahwa orang atau orang-orang tertentu telah melakukan tindak pidana meskipun telah ada perintah yang tegas kepada mereka agar hanya melakukan perbuatan yang tidak melanggar hukum;

4. Agar seseorang dapat dinyatakan bersalah karena melakukan tindak pidana, maka ia harus memiliki kalbu;

5. Untuk dapat menerpakan identifycation theory tersebut maka harus dapat ditunjukkan bahwa perbuatan yang dilakukan individu sebagai directing mind merupakan bagian dari kegiatan yang ditugaskan kepada individu tersebut. Perbuatan yang dilakukan bukan merupakan perbuatan curang yang ditujukan kepada korporasi. Serta tindak pidana yang dilakukan memberikan keuntungan kepada korporasi;

6. Pertanggungjawaban pidana korporasi mensyaratkan adanya analisis kontekstual atau dilakukannya analisis berdasarkan kasus per kasus.

Doktrin identifikasi ini dalam penerapannya tidak menyentuh pegawai yang memiliki jabatan yang digolongkan rendah dalam suatu perusahaan karena agar perbuatan individu tersebut dikatakan sebagai perbuatan yang dilakukan oleh korporasi maka individu tersebut haruslah bertindak sebagai directing mind. ${ }^{31} \mathrm{Hal}$ tersebut merupakan batasan dalam pertanggungjawaban pidana korporasi yang mensyaratkan adanya tindakan yang dilakukan oleh seseorang dengan kedudukan tinggi. 32 Cara menentukan directing mind adalah dengan melihat fakta-fakta ada kasus seperti kedudukan individu tersebut atau wewenang yang dimiliki sehingga dapat dikatakan bahwa perbuatan yang dilakukan individu tersebut memanglah

30 Aulia Ali Reza, Pertanggungjawaban Korporasi Dalam Rancangan Kitab Undang-Undang Hukum Pidana (Institute for Criminal Justice Reform 2015) 16.

$31 \quad$ Ibid., 17.

32 Karina Natalia, Pujiyono, Umi Rozah, 'Tinjauan Yuridis Pertanggungjawaban Pidana Korporasi dalam Tindak Pidana Pencucian Uang' (2016) 5 Diponegoro Law Journal 1, 10. 
perbuatan yang dilakukan oleh perusahaan.

Hulsman, guru besar hukum pidana dari Rotterdam, dalam pre-advisnya didepan perkumpulan Yuris pada tahun 1966, menyatakan bahwa unsur kesalahan yang berupa unsur kesengajaaan maupun unsur kelalaian dapat diadakan oleh organ-organ dari korporasi atau pekerja lainnya yang menetapkan kebijakan organisasi. ${ }^{33}$ Unsur kesalahan yang diperbuat dapat muncul secara tidak sadar dalam kerja sama antar pekerja. Dalam hal ini dapat diartikan bahwa peristiwa tersebut ada hubunganya dengan tindakan dari orang-orang yang bekerja dalam satu organ tersebut. Sedangkan Van Bemmelem memandang kesengajaan dari korporasi adalah pengetahuan bersama dari sebagian besar anggota direksi, Jan Remmelink menyatakan bahwa perbuatan korporasi adalah perbuatan yang dilakukan melalui perwakilan secara perorangan. Oleh sebab itu, unsur delik yang dilakukan oleh sejumlah orang yang berbeda. Hal ini akan menyulitkan dalam hal pembuktian dan menerapkan Pasal 15 ayat (2) tersebut karena untuk menentukan siapa-siapa saja pengurus yang dapat mewakili batasannya dimana dikatakan pengurus lainnya yang tidak menjadi tersangka atau terdakwa dapat mewakili Korporasi. Disini harus diperhatikan asas strict liability dan geen straf szonder schuld itu sendiri manakah yang lebih cocok diterapkan.

Suprapto berpendapat bahwa kesa- lahan korporasi dapat diambil berdasarkan kesengajaan atau kelalaian alatnya serta kesalahan tersebut tidaklah bersifat individual melainkan bersifat kolektif. Korporasi dapat memiliki kesalahan yang diambil dari pengurus atau direksi yang menjalankan tugas fungsionarisnya. Hal ini dikarenakan dalam berbuat atau tidak berbuat, perbuatan yang dilakukan oleh korporasi adalah perbuatan yang diwakilkan oleh perorangan di dalam organ korporasi tersebut yaitu pengurusnya. Asas kesalahan dapat dikenakan kepada pengurus korporasi. Pihak yang sejatinya dimintai pertanggungjawaban pidana semestinya cukup aktif terlibat dalam tindak pidana yang dilakukan oleh korporasi. ${ }^{34}$ Hal ini merupakan bentuk jaminan atas hak asasi manusia (HAM) yang harus dilindungi. Sebagaimana Indonesia juga merupakan negara hukum yang juga melindungi hak asasi warga negaranya. Hal ini tercantum dalam Pasal 1 ayat (3) Undang-Undang Dasar Negara Republik Indonesia Tahun 1945 sehingga negara Indonesia memiliki kriteria atau ciri-ciri sebagaimana konsep negara hukum Rechsstaat maupun konsep negara hukum The Rule Of Law. Menurut Jimly Asshidiqie terdapat 12 (dua belas) prinsip apabila negara dapat dikatakan sebagai negara hukum, salah satunya adalah perlindungan HAM. 35

Oleh karenanya, jika menurut ketentuan asas strict liability seseorang yang melakukan tindak pidana, meskipun tidak perlu dibuktikan adanya unsur kesalahan pada dirinya, namun

\footnotetext{
33 Ibid., 11.

34 Jan Remmelink, Pengantar Hukum Pidana Material 1 (Maharsa Publishing 2014) 128-129.

35 Aulia Ali Reza, Op. Cit., 10-13.
} 
tetap dapat dipertanggungjawabkan menurut hukum pidana, dan ketentuan asas geen straf zonder schuld yang merupakan pengecualiannya maka ketentuan penggunaannya haruslah dibatasi untuk kasus-kasus tertentu yang seharusnya dapat disebutkan secara tegas dalam peraturan perundang-undangan agar aparat penegak hukum tidak mengalami kebingungan dalam menerapkan asas untuk menentukan pengurus suatu korporasi dapat bertanggungjawab atau tidak. Meskipun dalam UU No. 31/1999 jo. UU No. 20/ 2001 tentang Pemberantasan Tindak Pidana Korupsi, pengurus juga dapat diwakili orang lain sebagaimana yang diatur di dalam Pasal 21 ayat (4).

Moeljatno memberikan pengertian terkait hukum acara pidana atau hukum formil yakni hukum yang mengatur tata cara melaksanakan hukum materiil (hukum pidana), dan hukum acara pidana adalah hukum yang mengatur tata cara melaksanakan /mempertahankan hukum pidana materiil. ${ }^{36}$ Dalam menentukan kesalahan korporasi yang dapat menjadi subjek hukum pidana maka dapat ditentukan sebagai berikut: 37

1. Pengurus korporasi berbuat, pengurus yang bertanggungjawab;

2. Korporasi berbuat tetapi tanggungjawabnya hanya pada pengurus;

3. Korporasi yang berbuat, korporasi yang bertanggungjawab;
Dikarenakan korporasi merupakan badan hukum yang tidak memiliki karakteristik seperti manusia sehingga korporasi tidak dapat melakukan tindak pidana tanpa melalui perantara pengurusnya sehingga berdasarkan teori pelaku fungsional maupun teori identifikasi maka dengan melihat apakah pengurus yang bertindak untuk dan atas nama korporasi memiliki kesalahan jika memang benar maka korporasi dinyatakan bersalah melakukan tindak pidana. ${ }^{38}$ Namun, hal berikutnya yang harus diperhatikan adalah kedudukan Perja dan Perma tidak termasuk dalam jenis dan hierarki peraturan perundangundangan, hanya diakui keberadaannya, sehingga hanya mengikat ke dalam. ${ }^{39}$ Sebagaimana mempertimbangkan pengaturan keterwakilan pengurus yang tidak menjadi tersangka dalam mewakili tindak pidana korporasi adalah melewati proses dalam hukum acara pidana yang berlaku yaitu mewakili korporasi40 yang menjadi tersangka dan terdakwa, meskipun dalam hal ini hukuman tetap dijatuhkan kepada korporasi namun keterwakilan ini seharusnya dibatasi pada pengurus yang memiliki kewenangan atau memiliki kapasitas tertentu dalam suatu korporasi. Oleh karena itu pengaturan tersebut perlu diatur dalam UU secara khusus dan secara umum diadopsi dalam revisi KUHAP di masa yang akan datang seba-

$36 \quad$ Andi Sofyan dan Abdul Asis, Hukum Acara Pidana Suatu Pengantar (Prenadamedia Group 2014$) 3$.

37 Hanafi Amran dan Mahrus Rusli, Op. Cit., 171.

$38 \quad$ Ibid.

39 Puteri Hikmawati, 'Kendala Penerapan Pertanggungjawaban Pidana Korporasi Sebagai Pelaku Tindak Pidana Korupsi' (2017) 8 Jurnal Negara Hukum 130, 149.

40 Korporasi merupakan subjek hukum yang tidak seperti naturlijk person yang dapat memberikan keterangan atau dapat melalui serangkaian hukum acara di pengadilan oleh sebab itu, keterangan dalam hal korporasi sebagai tersangka atau terdakwa sebagaimana yang diatur di dalam Pasal 1 angka 14 Perma No. 13 Tahun 2016 adalah keterangan pengurus yang mewakili korporasi. 
gai wujud perlindungan hukum.

\section{PENUTUP}

Terdapat ketidakjelasan menge-nai pengurus yang mewakili korporasi dalam hal korporasi melakukan tindak pidana apakah yang dimaksud sebagaimana pengertian korporasi dalam Perma No. 13/2016 yaitu organ korporasi yang menjalankan korporasi sesuai anggaran dasar atau, termasuk mereka yang tidak memiliki kewenangan untuk mengambil keputusan, namun dalam kenyataannya dapat mengendalikan atau turut mempengaruhi kebijakan korporasi atau turut memutuskan kebijakan korporasi yang dapat dikualifikasikan sebagai tindak pidana atau pengurus yang tidak memiliki kewenangan dalam korporasi sehingga terkait kriteria pertanggungjawaban korporasi yang ada dalam perma adalah strict liability yang mana terdapat pengecualian atas unsur kesalahan.

Pada asas strict liability seseorang yang melakukan tindak pidana, meskipun tidak perlu dibuktikan adanya unsur kesalahan pada dirinya, namun tetap dapat dipertanggungjawabkan menurut hukum pidana jika perbuatan orang lain yang berada dalam kedudukan sedemikian itu diklasifikasikan sebagai tindak pidana, dan ketentuan asas geen straf zonder schuld yang merupakan pengecualiannya maka ketentuan penggunaannya haruslah dibatasi untuk kasus-kasus tertentu atau benar-benar memiliki kewenangan dalam korporasi yang seharusnya dapat disebutkan secara tegas dalam peraturan perundang-undangan karena tidak ada batasan sejauh mana unsur kesalahan suatu pengurus dalam dapat diterapkan kepada pengurus yang mendapatkan perintah dari pimpinan suatu korporasi untuk mewakili sebagai tersangka atau terdakwa dalam persidangan.

Reformulasi peraturan perundangundangan terkait klasifikasi yang menentukan kesalahan pengurus yang dapat bertanggung jawab atau tidak khususnya memperjelas kekaburan makna dalam pasal 15 ayat (2) dalam pembentukan Perma No. 13/2016 ini adalah menjadi pedoman bagi penegak hukum nantinya, untuk mengatasi kekaburan norma khususnya mendorong optimalisasi penanganan pidana dengan pelaku tindak pidan korporasi dan/ atau pengurus dengan klasifikasi batasan yang tegas disertai dengan pembaharuan hukum acara pidana sehingga jelas posisi pengurus korporasi dalam hal menjadi tersangka/ terdakwa atau pengurus yang dapat mewakili korporasi sebagai terdakwa dalam persidangan.

\section{DAFTAR BACAAN}

\section{Buku}

Adriano, Pemikiran dan Teknik Pembuatan Putusan Pemidanaan Terhadap Korporasi (Mandar Maju 2016).

Amran, H. dan Ali, M., Sistem Pertanggungjawaban Pidana (Perkembangan dan Penerapan) (Rajawali Pers 2015).

Arief, Barda N., Pelengkap Bahan Kuliah Hukum Pidana I (Fakultas Hukum 
Universitas

Semarang 1984).

Kapita Selekta

Hukum Pidana (Cetakan ke-3, Citra Aditya Bakti 2013).

Huda, C., Dari Tiada Pidana Tanpa Kesalahan Menuju Kepada Tiada Pertanggungjawaban Pidana Tanpa Kesalahan (Prenadamedia Group Jakarta 2017).

Muladi \& Priyatno, D., Pertanggungjawaban Pidana Korporasi Edisi Revisi (Prenada Media Group 2012).

Prawennei, M. dan Tomalili, R., Hukum Pidana (Penerbit Mitra Wacana Media 2015).

Purwoleksono, Didik E., Hukum Pidana (Airlangga University Press 2015).

Remmelink, J., Pengantar Hukum Pidana Material 1 (Maharsa Publishing 2014).

Reza, Aulia A., Pertanggungjawaban Korporasi Dalam Rancangan Kitab Undang-Undang Hukum Pidana (Institute for Criminal Jutice Reform 2015).

Sofyan, A. dan Asis, A., Hukum Acara Pidana Suatu Pengantar (Prenadamedia Group 2014).

Suartha, I Dewa M., Hukum Pidana Korporasi (Pertanggungjawaban Pidana dalam Kebijakan Hukum Pidana Indonesia) (Setara Press 2015).

\section{Artikel Jurnal}

Hikmawati, P., 'Kendala Penerapan Pertanggungjawaban Pidana Korporasi Sebagai Pelaku Tindak Pidana Korupsi' (2017) 8 Jurnal Negara Hukum.
Krismen, Y., 'Pertanggungjawaban Pidana Korporasi dalam Kejahatan Ekonomi' (2014) 4 Jurnal Ilmu Hukum.

Natalia, K., Pujiyono, dan Rozah, U., 'Tinjauan Yuridis Pertanggungjawaban Pidana Korporasi dalam Tindak Pidana Pencucian Uang' (2016) 5 Diponegoro Law Journal.

Situmorang, Jegesson P., Pujiyono dan Soemarno, A., Pertanggungjawaban Pidana Korporasi dalam Menanggulangi Tindak Pidana Perikanan' (2016) 5 Diponegoro Law Journal.

\section{Peraturan Perundang-Undangan}

Undang-Undang Nomor 8 Tahun 1999 tentang Perlindungan Konsumen.

Undang-Undang Nomor 31 Tahun 1999 tentang Pemberantasan Tindak Pidana Korupsi sebagaimana telah diubah dengan Undang-Undang Nomor 20 Tahun 2001.

Undang-Undang Nomor 36 Tahun 2009 tentang Kesehatan.

Undang-Undang Nomor 32 Tahun 2009 tentang Perlindungan dan Pengelolaan Lingkungan Hidup.

Undang-Undang Nomor 31 Tahun 2014 tentang Perlindungan Saksi dan Korban.

Peraturan Mahkamah Agung Nomor 13 Tahun 2016 tentang Tata Cara Penanganan Korporasi.

Peraturan Mahkamah Agung Nomor 13 Tahun 2016 tentang Tata Cara Penanganan Korporasi.

\section{Internet}

Anonim, 'Mendorong Penegakan Perta- 
nggungjawaban Korporasi Dalam

Perkara Pidana: Perma No.13 Tahun

2016 dan Tantangannya' (2017)

$<$ http://icjr.or.id/mendorong-pene

gakan-pertanggungjawaban-korpo

rasi-dalam-perkara-pidana-perma-

no-13-tahun-2016-dan-tantangan

nya/> diakses 15 Mei 2018.

Dharmadji, Stefanus K., 'Pertanggungja-

waban Pidana Korporasi Pasca

Perma No. 13 Tahun 2016' (2017)

$<$ http://weloje.id/news-posts/perta

nggungjawaban-pidana-korporasi-p

asca-perma-no-13-tahun-2016/>

diakses 15 Mei 2018.

Nasution, D., 'Siapakah Yang Bertanggungjawab Jika Terjadi Tindak

Pidana Korporasi?' (2017) <https://bplawyers.co.id/2017/07

/11/siapakah-yang-bertanggung-ja wab-jika-terjadi-tindak-pidana-kor porasi/> diakses 15 Mei 2018. 
